\title{
家族の民主化
}

戦後家族社会学の〈未完のプロジェクト〉

\section{阪井 裕一郎*}

本稿は, 戦後家族研究の再検討を通じて,「家族の民主化」という理念が, 個人化や多様化によって特徵づけられる後期近代においても，なお重要な理念 であることを明らかにするものである.

本稿ではまず，戦後すぐに家族研究の課題として揭げられた「家族の民主 化」の理念とその限界を再考する。 これまで民主化論には数多くの批判がなさ れ，近年の家族社会学でこの用語が理念として取り上げられることはなくなっ た。しかし，民主化論に対する批判は，その限界が，民主化の理念そのものに ではなく,「家族の例外化」という前提にあったという重要な問題点を看過し てきた。ここでは, 戦後の民主化論が「家族の例外化」に立脚してきたことを 問題化したうえで,「家族の民主化」の実現の可能性を A. ギデンズの「親密性 の変容」や「民主的家族」の議論から探究する。ギデンズの議論にもまた多く の批判が寄せられているが, これらの多くはギデンズの意図を正確に把握して いない可能性がある．ギデンズの議論は，近年高まりつつある「家族の脱中心 化」の議論へと接続することではじめて有効になると思われる，そして，「家 族の民主化」という理念が「家族の脱中心化」という理念と相補関係にあるこ とを明らかにする。

家族関係と民主主義の原理は相容れないとする前提こそが，これまでの家族 論の背後仮説であった。 しかし, 必要なのは家族と民主主義の関係を真摰に検 討することであり，「家族の民主化」という理念を〈未完のプロジェクト〉と して, 家族社会学の中心的課題へと引きもどすことなのである.

キーワード : 家族の民主化, 親密性の変容, 家族の脱中心化

\section{1 問題の所在}

戦後 10 年以上が経過し,「逆コース」と呼ばれる時代趨勢にあった 1958 年,「家 族の民主化」の代表的論者であった磯野誠一・富士子夫妻は次のように述べた.

* 慶應義塾大学文学部非常勤講師 yuichiro.sakai@hotmail.co.jp 
「明るい民主的な家庭」のスローガンは，近代家族の直面する現実の難問題 をおおう危険な幻想である。……家族制度の温情主義は, 現在もなお成人の大 多数を占めている敗戦後の世代の常識にぴったり合致する。…民主的な家庭 は必然的に明るいのだと説くのは，理論的にも誤りであり，また，家族の真の 民主化に役立つものとは思われない。 民主的な家庭の理想は，「明るい民主的 な家庭」であるが, 家族制度における理想も, 一家の和合団欒だったのである から，「明るさ」をもって，民主的であることの特長とすることはできない.

(磯野・磯野 1958: 164-6)

このような叙述は，われわれの抱く「家族の民主化」論のイメージとはいくぶん 異なるものであろう。これまで, 戦後の民主化論者による家族論は「愛情に満ちた 明るい家庭」という西欧市民家族を無批判に受容してきたことが，家族社会学やフ エミニストの研究で糾弾されてきた（上野 1994; 牟田 1996; 千田 1999).

しかし, 磯野夫妻の言葉にも見られるように, 当時の「民主化」論者たちの著述 をみていくと, 彼らが, 民主的家族における「愛情」に対してアンビバレントな態 度を有していたことがうかがえる（川島 [1947] 2000 ; 北村 1955; 磯野・磯野 1958). 事実, 『国体の本義』や『教育勅語』といった戦前の啓蒙書は, 一同に 「和」や「情」の重要性を掲げていたのであり, 民主化論者は, 新たな家族の理念 を単純に「情緒性」の面から強調することに対して強い危機意識を共有していた (磯野・磯野 1958: 114).

こうして戦後日本の「家族の民主化」論を読み返せば，これまでの「民主化」批 判ははたして妥当だったかという疑問が生じる．「民主化」論の限界はもっと別の ところにあったのではないか. 本稿は,「民主化」論が十分な検討を経ることなく 過小評価されてきたこと，そして，その真の限界が的確に把握されなかったことが, 現在の家族社会学が抱える, 過去の研究との断絶や「問題意識の共有の希薄化」 （田㴊 2006）といった混乱の一因ではないかという認識に立つ.

1980 年代以降, 家族社会学では, 近代家族（批判）論が隆盛し，われわれが 「自明」としてきた「家族モデル」が「愛情」の名のもとに「権力」や「抑圧」を 隠蔽してきたイデオロギーにすぎなかったことが暴露された，それゆえ，権力や規 範からの解放として特徴づけられる, 家族の「個人化」や「多様化」こそが進むべ き方向性であると考えられた。しかし現在, 階層不平等の拡大やリスクの高まり, 社会的孤立の増大など「個人化／多様化」のさまざまな負の帰結に直面し，ふたた び「個人化」論に対する反省的・批判的な機運が高まりつつある. そのなかで家族 社会学が「社会的連帯」の可能性を模索する必要が唱えられているものの, 明確な 理念を打ち出すことができずにいるというのが現状であろう.

とはいえ, 社会学は「個人化」批判には慎重であるべきではないか. 山手茂が指 摘したように，そもそも「『家』制度を廃止し，家族を近代化＝民主化することは， 明治以来, 日本社会の近代化・民主化のための重要な課題であった」（山手 1975: 
61）のであり，民主主義の台頭と「家族の危機」論の対立という構図は，明治期以 来綿々と繰り返されてきた言説の構図にほかならない1).さらに言えば，後期近代 の階層化やリスク化といった問題を，たんに「家族の個人化」の帰結だと捉えるな らば，「家族問題に原因を還元する」という意味で，これも一種の「家族中心主義」 にほかならない，そして何より，家族社会学の中心的課題であった「近代家族」批 判は, 男性中心主義や異性愛主義といった権力関係を可視化することで, 家族が十 分に「民主化」されていないことを問題化してきたはずである，換言すれば，「家 族に扔ける民主的関係」の追求こそが，家族社会学のアイデンティティだったので ある。

本稿では以下, 家族の「解消可能性」や「選択可能性」の増大という「実態」を 示す概念として「家族の個人化」(山田 2004), 家族関係に打ける「平等, 自由, 自主性, 討議, 暴力からの自由」といった「理念」を示す概念として「家族の民主 化」という概念を用いることにするが,「民主化」の推進は必然的に「個人化」に 州結することになる2). となれば，われわれはいかにして民主化の理念を保持した まま個人化に伴う諸問題に対処すべきかを検討する必要がある。つまり，家族社会 学は，個人化の進行をただ否定的にとらえ「家族関係に民主主義は適用できない」 という前提を是認することだけは回避しなければならない，本稿は，こうした問題 を脱却するために，「家族の民主化」の理念の再検討が不可欠だという視点に立つ. 家族と民主主義の関係を真摰に検討しなければ，われわれは今後も「民主主義」の 主張と「家族の危機」論のゆれ戻しを繰り返すことになる。

そこで，本稿はまず，戦後の「家族の民主化」論を再検討し，これまでの民主化 論批判の妥当性を問い返す。ここでは,「家族の民主化」批判が看過した「民主化」 論の限界を明確にしていく(第 2 節)。そのうえで, 近年ギデンズが提唱している 「民主的家族」の理念と彼への批判を検討する (第 3 節)。最後に，ギデンズの議論 を，近年の「家族の脱中心化」をめぐる議論へと接続することで，「家族の民主化」 がなぜ今なお重要な理念であるのかを明らかにする(第 4 節).

\section{2 「家族の民主化」論再考}

まずは,「『家族の民主化』論の時代」（山手 1975; 湯沢 1977）と区分される 1950 年代頃までの議論を検討しょう。戦後日本の最重要かつ喫緊の課題は, 社会 関係の民主化にあったが, 家族研究の関心もまた家族領域における「民主化」の推 進にあった (我妻 1948) ${ }^{3)}$.「家族の民主化」の代表的論者であった川島武宜 （[1946] 2000）は，社会に根づく「家族的原理」こそが「社会生活の民主化」の妨 げであり，「民主主義的な家族形態・家族原理」の実現によって「真の民主主義」 が成立すると考えたのである. 


\section{1 「家族の民主化」批判の再検討}

川島は，論文「日本社会の家族的構成」([1946] 2000) で,「家族的原理」が 「民主主義の原理」といかなる関係にあるかを検討することが家族研究の課題だと 宣言した，川島はまず，戦前の家族制度を「武士的=儒教的家族」と「庶民家族」 の 2 つに峻別したうえで，その両者が，「人が自らの行動について自主的に判断し， 決定すること」や「人格の相互的な尊重」に特徴づけられる「民主的＝近代的な社 会関係の原理」とは異なるものであったことを問題視した（川島 [1946] 2000：5）. 川島は，個人の人格・権利を尊重し，夫婦や親子の対等な関倸の実現を「民主化」 の理念に掲げた.

こうした川島の問題意識は, その他の家族研究者たちにも強い影響を与え, たと えば，当時の文献で頻繁に引用された『近代家族』の著者北村達は，「民主的家族」 を「近代家族」ととらえ, その重要な要素を「討議」「開放性」「平等」「自由」で あると述べた（北村 1955).

現在まで家族社会学は，このような「民主的家族」の理念を批判してきたが，こ こではまずその批判の内容を検討していきたい.

第 1 に，とくに近代家族（批判）論の文脈でなされたのは，民主化の理念が「男 性中心主義」や「家父長制」を温存してきたという批判である（牟田 1996; 千田 2010)．民主化論者が理念とする「市民社会」における「市民」とは男性のことに ほかならず，家族関係に潜む男女不平等は問題化されなかったという指摘である. しかしながら，当時の文献を見れば，論者たちはいずれも「民主的家族」の重要な 理念として執拗なまでに「男女の平等」を揭げていることがわかる．民主化論が 「意図せざる結果」として家父長制を温存させたという批判はたしかに正当かつ有 意義なものであるが, 民主化論者が, 男女不平等の問題に無自覚であったと断定す るのは無理がある，となれば，民主化論者たちが，男女平等の実現を目標に揭げて いたにもかかわらず，なぜそれが実現されえなかったのかという問題意識から彼ら の限界を探る必要があると思われる.

第 2 に，民主化論者たちが，めざすべき「近代的家族＝民主的家族」を「西欧市 民家族」と同定し，西欧型家族自体にはらまれる問題を等閑視したという批判があ る（牟田 1999；千田 1999，2010）。牟田和恵は，「川島は西欧市民家族を『民主的 で近代的』な家族結合の範としたが，現代のわれわれは，それが性と世代の役割分 業に構造化されていたことを知っている，保護する親と慈しまれる子は，子を管理 する親と自己決定権を奪われて監視される子の姿と表裏である. 家庭の中心に位置 して暖かい家庭を作る，よき妻・母と称揚される女性は，実は家庭外においては夫 たる男性の被保護者としてしか存在を認められず，法的・社会的な無能力者に他な らなかった。..... 『近代的家族』に扔いて個人としての自由を享受するのは，家族 の全員ではないのである」(牟田 1996: 131）と述べる.

しかし，このような批判はやや極端であると思われる．冒頭に述べたように， 「民主化」論者の多くは, 愛情に満ちた「西欧市民家族」を無批判に肯定したとは 
いえず，それがはらむ緊張や葛藤の問題に自覚的であった. とくに，1954 年の憲 法改正論議以降に高まった「家族制度復活論」に抗うため, 家族研究者たちは「民 主的=明るい家庭」の理念を掲げることへの危機感を共有していたのであり，「民 主的家族」の理想が単純に「明るさ」を強調するだけでは実現不可能であることを 認識していた ${ }^{4)}$ ，それゆえわれわれは，民主化論者が「愛情」に対するアンビバレ ントな態度をもちながらも，なぜ最終的には家族における「愛情」に絶大な信頼を 置くことになったのか，を問う必要があるだろう。

\section{2 家族関係の例外化一一民主化」論の陥䆥}

では，「家族の民主化」論の真の限界は何だったのか．結論から述べれば，それ は社会関係に掯ける「家族関係の例外化（あるいは特権化）」であったといえる. ここで「家族の例外化」と呼ぶのは, 家族関係をその他の社会関係とは異質な例外 的なものであると位置づけ, 家族の「構造」の内部で担うべきとされる「家族機 能」を家族でしか担完ないものであると「本質化」してしまう見方をさす.

当時の「家族の民主化」論は内容に多少の違いはあれども，「家族の例外論」を 前提にしている点で共通していた．たとえば，「近代家族＝民主的家族」の代表的 論者の 1 人である北村は,「家族外の社会集団は確かに自由主義, 合理主義, 個人 主義が支配しているが, 家族のみは完全に個人化, 合理化されない事」であり, 「家族成員も徹底的に個人主義化」すれば「最早家族としての存在意義を失って終 わって」しまうと述べている（北村 1955：6）。北村は, このように他の社会関係 のなかで家族関係だけは例外的なものとして位置づけたがゆえに，最終的に家族の 結合を「愛情」に頼らざるをえなくなる，「家族個人の人格は平等であり，個人の 責任が重んぜられる」と述べる北村は，「近代家族は愛情によって一体化される集 団」であり「本能的な愛情によって結ばれ，それが基盤となっている」として， 「不安定性の強い近代家族」を愛情によって結合していかなければならないと述べ た（北村 1955: 41).

また，「家族の民主化」の理念が内包する危険性にもっとも敏感であった磯野夫 妻もまた，最終的には「愛情」のみが民主的家族の基盤になると結論している．磯 野夫妻は, 「家族関係と他の人間関係との本質的な差は, そこにおける愛情の重要 性である」と述べ,「近代家族に最後まで残される機能は, 子供の性格形成と, 個 人の情緒的安定を保つこと」だと断定し次のように述べる.

家族内と家族外との人間関係の根本的相違は，権利義務関係の存在・非存在 ではなく，この愛情の持つ重要性の相違に他ならない.いいかえれば権利の主 張の放棄，抑制を苦痛と感じさせず，あるいは，権利の主張によって生ずる緊 張にも耐えうるような愛情があることが, 近代家族が家族として存続するため に絶対に必要なのである。（磯野・磯野 1958: 189） 
じつは民主化論者たちのこうした「愛情への信頼」は，彼らが依拠していた，E． W. バージェス, H. J. ロック, J. K. フォルサムといった欧米の家族研究者にも共通 するものであった。「民主的家族」を理想化した社会学者たちもまた「家族関係の 例外論」に立脚し，「愛情による結合」こそが唯一の理念だと考えていた (Burgess and Locke 1945; Folsom 1949)。 そして，このような前提が，核家族を自 明とした「標準理論」の下地を用意したのである.

山田昌弘（1994；1999）が繰り返し指摘してきたように, 近代家族は「愛情」を 家族結合の唯一の基礎であるとみなし，「家族の愛情は自然に任せればうまくいく という『予定調和』説」を前提としており, それゆえ愛情の名のもとに鿵蔽される 暴力に無自覚であった（山田 1999: 141）。本稿の検討を経由すると, こうした愛 情への信頼を支えていたのは，じつは「家族の例外化」であったといえる.

本節の知見を整理しておこう。「家族の民主化」論者は，「情緒的な絆」のみを根 拠に民主的家族を称揚することが危険であると自覚していたにもかかわらず，結局 は愛情のみが民主的家族の根幹であると主張する, というアンビバレンスを抱えて いた5)。これは, 家族関係は解消困難かつ選択不可能な存在である, という家族の 例外化を前提として,「家族の枠内での個人化」(山田 2004) をめざしたことの必 然的な帰結であった。「家族の民主化」の限界は, その理念自体にあったのではな く，それを「家族の例外化」に立脚したまま実現しょうと考えた点にあったのであ る.となれば，われわれは「民主化」の理念を家族の「脱例外化」の文脈へと接続 していかねばならない.

\section{3 後期近代における民主的家族}

現在，日本の家族社会学では「家族の民主化」は否定的に語られることこそあれ， それが理念として明示されることはほとんどない. しかしその一方で, 家族の個人 化や多様化に特徴づけられる後期近代にあって，モダニティ論の挛引者の 1 人 A. ギデンズは，近年その著作のなかで「民主主義としての親密性（intimacy as democracy)」（Giddens 1992; Giddens and Pierson 1998）や「感情の民主主義 (emotional democracy)」(Giddens 1994)，「民主的家族（democratic family)」(Giddens 1998）といった家族関係に扔ける民主主義の可能性を提唱している. 日本では「家 族の民主化」という言葉に否定的なイメージがつきまとうためか，ギデンズの「親 密性の変容」論で提示されている「民主主義」の議論にまで踏み込んだ研究はほと んど見られない，本節では，一見アナクロニズムにさえ映るギデンズの「民主的家 族」の理念と，彼への批判を検討することで，後期近代における「家族の民主化」 論の可能性を探る.

\section{1 ギデンズの「家族の民主化」論}

ギデンズは『親密性の変容』(Giddens 1992) の終章で初めて「民主主義として 
の親密性」という議論を展開した．周知のように，ギデンズは家族関係や友人関係 のような人々の親密な関係性が「外的な準拠枠組」を喪失し，関倸性そのものに内 的に準拠していく事態を,「純粋な関倸性」として定式化した，彼は，家族関係や 家族以外で形成される親密関係が「純粋な関係」化していくことを，後期近代の不 可避な趨勢であるとし，この関係性が有している「民主主義の可能性」を肯定的に 捉えようとしたのであった.

ギデンズは，より実践的な政策提言を含む著書『左派右派を超えて』や『第三の 道』といった著作でも，「感情の民主主義」「民主的家族」の理念を掲げる．これら の著作を通して，公的領域に扔ける民主主義の原理を私的領域にも拡大していくこ との必要性を繰り返し説いている.

ではなぜ,「純粋な関係性」に特徵づけられる後期近代の関係性のあり方が「民 主主義」の可能性をもつのか. ギデンズによれば,「純粋な関係性」は, 嗜癖のよ うな問題を引きおこすリスクがあるにせよ，平等，相互尊重，自主性，対話，暴力 からの自由といった特徵をもつ関係性である，それゆえ関係性の純粋化は，規範や 権威に規制されていた伝統的家族とは対照的に, 当事者が互いに平等な権利を有し ているがゆえ, 問題点を潜在化させることなく, 対話を通じて能動的に創り出し維 持していく，「暴力の懸念のない関係性」となる（Giddens 1992; Giddens and Pierson 1998).

家族の文脈における民主主義は，平等，相互尊重，自主性，討議に基づく意 思決定, 暴力からの自由に, 特に大きな価值を置く，民主的な親子関係のあり 方は，こうした価值規範から導くことができる，親が子に対して，親の権威の 正当性を主張するのは当然のことである. しかし，親の権威の何たるかは，親 子の話し合いによって決まるのであり, 最初から決まった定型があるわけでは ない，家族の価值規範は，異性愛家族のみならず，同性愛家族にも適用される。 (Giddens 1998: 93-4)

また，ギデンズは，新たな家族の指針となるのは「民主主義」以外にないと宣言 しており（Giddens 1998：93），「民主的家族」の特徵として，「感情と性の平等」 「家族内での対等な権利と義務」「子どもの共同養育」「親子関係の生涯契約」「子ど もとの話し合いに基づく親の権威のあり方」「社会に統合される家族」などを揭げ る.

ギデンズのこのような見解は，その当初から多くの批判を受けてきた．その批判 内容を見ていこう.

\section{2 「親密性の変容」批判の検討}

ギデンズの掲げた「民主主義としての親密性」という理念に対する批判の矛先は, 何よりもその「楽観主義」に向けられたといえる．たとえば，ギデンズの議論には 
拡大しつつある不平等の問題への視点が欠如しており，階級など経済的・文化的側 面への配慮が欠落していると批判されてきた（Bauman 1993; Bologh 1994; 山田 2004)。「純粋な関係性」を肯定することは，現実に生じている不平等の問題を隠蔽 することになるという指摘である，また，ギデンズが肯定的にとらえる「純粋な関 係性」は，昨今のセラピー文化の「心理主義的言説」と親和的であり，それを補強 するものでしかないという批判もなされている (Jamieson 1999).

これらの批判者たちの問題意識の根底には, 近年の「個人化」がもたらした負の 州結があると思われる. 欧米と同様, 日本の家族社会学においても,「格差」や 「貧困」は重要な議題になっており, これまでのように「家族の個人化」を肯定的 にとらえる見方に反省を促す傾向が強まっている（山田 2004; 池岡 2010; 岩間 2010；小玉 2010 など).

たとえば，山田昌弘は，「家族関係自体を選択したり，解消したりする可能性が 増大するプロセス」は，「家族の本質的個人化」（山田 2004：344）と呼ぶべき事態 であり，これが，家族の「リスク化」と「階層化」をもたらしたと指摘する．家族 関係についての選択可能性の増大は, 家族関係が望んでも得られるとは限らず, つ ねに解消可能性と隣り合わせになる「家族のリスク化」をもたらし, さらに「自分 が選んだ選択肢の実現可能性は, 家族内部の力関係だけではなく, 社会全体の中で の個人の『力』関係に依存するようになる」がゆえ,「社会全体の中での自分の魅 力, 経済力の序列が問題になる」ような「家族の階層化」をもたらす（山田 2004: 349-50). 山田は, これまで「個人化」は「規範からの解放」を意味すると把握さ れたがゆえに肯定的に受容される傾向にあったが, リスク化や階層化の進行を前に， われわれは「『選択不可能』『解消困難』な関係なしで, 近代社会が成立するかどう かを考えなくてはならない状況に入っている」と危惧している（山田 2004: 352）.

また，ギデンズへの直接的な批判ではないが，池岡義孝は「核家族パラダイム」 批判のあとに登場した「家族の多様化・個人化」を推進する家族研究の方向性が, 「個人化できる, 多様化できる余裕のある層には適合的で, 自らの人生を展開して いく指針となりえたが, 経済格差や教育格差によって個人化できない, 多様化でき ない層には有効な手段とはなりえなかった」と述べ，「この間生じてきたさまざま な家族問題を, 家族多様化説, 個人化説, そして近代家族論が一時的にであれ隠蔽 する働きをしたのなら，それらの功罪を含めて再検討する必要がある」と「個人 化」や「多様化」への楽観的見解に反省を促している（池岡 2010：151）.

たしかにこれらの説得力のある主張は,「個人化」によって生じた現代の問題を 把握するための重要な視点を提供する. しかしながら,「個人化」への批判は, 家 族社会学のアイデンティティの根幹を否定することにもなりかねないがゆえ慎重さ を要する，というのも, 戦後の「家族の民主化」論にしろ,「近代家族」批判にし ろ，これまで家族社会学は，一貫して「家族の民主的な関係」こそを模索してきた のであり, もしその帰結として家族の解消可能性や選択可能性の増大が生じている のであれば，これまでの議論を踏襲したうえでの建設的な議論を展開しなければな 
らないはずだからである。それこそが「家族社会学のアイデンティティ」のために 不可欠であろう.

もちろん, ギデンズの見解を批判する論者の多くも, 彼の「現状分析」を批判し ているというよりは，彼の「楽観主義」を批判する傾向にあるといえ，「純粋な関 係性」の出現に社会学がどう対応していくべきかという問題意識そのものは共有さ れているといえる.

「家族の個人化」の進行はたしかにわれわれの社会生活に新たな問題を投げかけ ている.しかし，だからといって「家族の民主化」を不可能な理念であるとみなし， その理念自体を否定するならば，「家族関係に民主主義は適用できない」という 「家族関係の例外化」の是認へと舞い戻るだけだろう ${ }^{6)}$ 。このジレンマを脱却する ために，われわれは「家族の民主化」を〈未完のプロジェクト〉と位置づけなおし， この理念に修正を施しつつ，継承していくべきではないだろうか. ギデンズが唱え る「民主的家族」の理念には，こうした「近代批判と伝統回帰」の「繰り返される 振り子の摇り戻し」(小玉 2010：163）を脱却する可能性が潜在している. 次節で は，個人化する時代にあって，なぜ「家族の民主化」という理念が重要であるのか， ギデンズの「社会に統合される家族（socially integrated family)」(Giddens 1998) という概念に焦点をあてて検討していこう.

\section{4 〈未完のプロジェクト〉としての「家族の民主化」}

ここでは，ギデンズの掲げる「民主的家族」を，われわれがなぜ擁護しなければ ならないのか, その根拠を明らかにしていく，ギデンズの「親密性の変容」論はこ れまで数多くの文献において引用・批判がなされてきたが, そのなかで見落とされ がちなのは, 彼が「個人の選択」と「社会的連带」を結びつけるために「民主的家 族」の理念が重要だと主張している点である (Giddens 1998: 93). ギデンズは, 「家族の強い絆は，それが家族の内側のみにとどまらず，外側にも及んで初めて市 民的結束（civil cohesion）の有効な基盤となる」（Giddens 1998：98）と述べ，民 主的家族とは「社会に統合される家族」だと強調する，ギデンズのこの主張の意図 は，おそらく彼自身の説明不足に因るところもあるが，正確に理解されてこなかっ た．ギデンズの意図を理解し生産的な議論を構築するためには，「民主的家族」の 理念を, 家族社会学の領域で近年高まっている「家族の脱中心化 (decentralizing the family)」や「福祉の脱家族化」(Esping-Andersen $2008=2008$ ), さらには, 「公的領域と私的領域の再編成」(Budgeon and Roseneil 2004a；上野 2009）といっ た議論の文脈へと接続していくことが不可欠だと思われる.

\section{1 家族の「民主化」と「脱中心化」}

まずは，ギデンズが「親密性の変容」を「社会的連帯」の文脈で語っていること に注意を喚起したい（Giddens 1994, 1998）。ギデンズの「社会に統合される家族」 
は，これまで家族に担われてきた，あるいは家族が担うべきと自明視された諸機能 を社会的に共有していこうというメッセージを含んでいる.

たとえばギデンズは，「民主的な家族関係は，男女間の，そして親と親でない人 の間の, 育児責任の分担の見直しを迫ることになる」(Giddens 1998：93）と述べ， 「民主的家族」の理念が「ケアの役割」をめぐる責任の見直しを迫るという。たし かにギデンズは「子どもの養育」を事例に取り上げるのみで，その他の具体的な社 会的連帯の方向性に関してはほとんど語っていない.

とはいえ，ここには，従来「家族」のみに集中されてきたリスクと責任を社会的 に共有していくべきだという認識を垣間みることができる，こうしたギデンズの議 論は，近年高まりつつある「家族の脱中心化」論の文脈へと接続されることで，よ り説得力と有効性を増すだろう，逆説的に響くかもしれないが，本稿の結論を先取 りすれば,「家族の民主化」は，「家族の脱例外化＝家族の脱中心化」の文脈に接続 されてはじめて実現可能となるのである.

では,「家族の脱中心化」とは何か. 本稿では, 従来「家族機能」として異性愛 主義に基づく家族という「構造」の枠内で充足されるべきとされてきた諸機能を, 家族以外の社会関係に分散（decentralize）させていくべきだという一連の議論を 総称して「家族の脱中心化」論と呼ぶことにする (Budgeon and Roseneil 2004a, 2004b; Pahl and Spencer 2004)。これは, G. エスピン - アンデルセンが繰り返し述 べてきたような，高齢者介護や子どもの養育といった福祉機能を，家族のみに集約 させる社会制度を見直し、「福祉の脱家族化」を促すべきだという議論に象徵され る (Esping-Andersen 2008=2008).

日本の家族研究でも，「脱中心化」という用語を用いずとも，同様の議論が活発 化している，たとえば，久保田裕之の一連の研究をあげることができる（久保田 2009a, 2009b, 2011)。久保田は, 従来の「家族機能論」が,「「ず家族の範囲を確 定し，次に機能の数を数え上げる」という「手続き的な前提」に依拠していたこと を批判する（久保田 2011：81）。久保田は，必ずしも家族という「構造」をもたず とも「家族機能」が担われている多くの関係が存在しうる現状をふまえれば，家族 機能を家族構造から分化させることが必要であるという。そして，「依存」や「親 密性」「生活の共同」といった「機能」を充足しうる家族以外の多様な社会関係が 存在しうると指摘し,「機能の偶発的な重なり合いの中に家族を説明可能なものと して再定位すること」，すなわち，家族を「機能的必然」から「偶発的」な存在へ と読み替えることが必要だと述べる（久保田 2011：89）.

また，上野千鶴子（2009）がM. ファインマンを援用しつつ提唱する「依存の脱 私事化」の議論もまた，「家族の脱中心化」論と共鳴するものであろう。「近代家 族」とはそもそも「依存の私事化」によって成立したものだが，「近代家族」がそ の信頼性を峦失した今,「依存」は, 家族を超えた多様な社会関係のなかに再定位 される必要がある。その意味で,「家族の脱中心化」とは公私領域の再編成を意味 する (Budgeon and Roseneil 2004b)。おそらくこれまでならば,「形容矛盾」とし 
か捉えられなかったような, “personal communities” (Pahl and Spencer 2004) や, “intimate solidarity”（Santore 2008）といった概念への注目の高まりは，公私再編 成の機運を象徵的に示すものだといえよう.

では，このような「脱中心化」論がなぜ「家族の民主化」と密接に関わるのだろ うか.

第 2 節で指摘したように，「家族の民主化」は，家族関係を「例外化」したまま では実現困難であり，家族や個人に対する社会の積極的な保護・介入によって実現 しうる.「家族の民主化」を理念として承認することは, 必然的に家族の解消可能 性と選択可能性を高めることになるが，このことは家族外部の関係も家族機能を担 うべきだとする「家族の脱中心化」の理念に正当性を付与する.

また，福祉機能が「脱家族化」したり，個人が所持する関係性が家族関係に限定 されなくなれば，家族内部における個人の権利や自由の行使が活性化される。つま り，「脱中心化」の理念が「民主化」を保障し，促進する機能をもつ.

つまり，「家族の民主化」と「家族の脱中心化」は相補関係にあるということで ある。これまで政策レベルでは, 家族の「解体」や「病理現象」の増加といった問 題に対して，「標準的な家族」を見直し再強化することで解決しょうという提言が なされる傾向にあった．しかし，エスピンーアンデルセンが「福祉の脱家族化は家 族の絆を壊す」という思い达みが存在するが「事実はその反対を示している」 （Esping-Andersen 2008=2008：37）と述べるように，実際には，「家族の民主化」 こそが「家族の脱中心化」を促進し，また，「家族の脱中心化」の推進こそが「家 族の民主化」を促進するという相補関係にある7 . 家族を権力や暴力の規制から解 放し，自由で平等な関係にしようという「民主化」の理念が，家族関係から離脱し た人々に対する「保護」の視点を可能にし，また，「家族」に限定されない社会的 連帯の選択肢を評価する「脱中心化」の理念が，家族内の関係の「民主化」の促進 に寄与するという，相互に保障・促進しあう関係にあるのである.

\section{2 個人化と連帯}

以上述べたような，「家族の民主化」を促進し，社会が家族に積極的に介入すべ きだという見解は, 公権力による私領域の管理を是認するという意味で, 人々の 「自由」を脅かすものだとして批判を受けるかもしれない.「家族の民主化」を重要 な理念だと主張するためには，「家族の民主化」における「自由」の意味を明確に しておく必要がある.

民主主義の徹底は, 当然のことながら,「個人の自由」の促進を企図するものだ が, ここで「自由」を単純に「無規制」や「無規範」と把握すべきではない．そも そも,「自由の拡大」の結果,「家族の個人化」が生じたというロジックは, 間違い とは言い切れずとも，1つの矛盾を不可避的に抱え込む．なぜなら，家族の個人化 ないし多様化に伴って生じているのは,「リスク化」や「階層化」といった「不自 由」の増大とも呼びうる状況だからである。つまり，個人化の原因を「自由の拡 
大」で説明する論法は，多くの人々が被っている「不自由」を解釈するための回路 を閉ざす危険をはらむ。このようなアポリアを脱却するために，「自由」という言 葉の検討が必要なのである.

そもそも社会学の伝統に立ち返れば，「自由」と「統制」はゼロサムで捉えられ るものではない． É.デュルケムは「自由それ自体が規制の産物である」(Durkheim 1893=1971：3）と述べ，K. マンハイムは「民主主義」の実現のためには，「統制」 を通じて「自由」を確保すること（=第三の道）が必要だと提唱したのであった (Mannheim 1951 = 1976).

彼らが危惧したように，もし「自由」を「放任」と同一視すれば，社会は弱肉強 食の不公正を野放しにすることになる8)。、ンハイムによれば，「計画的社会にお ける自由は, 官僚制や規制が存在するか否かによってではなくて, 公共の利益と個 人的可能性の最大限の活用とがどうであるかによって判断されるべきである」 （Mannheim 1951 = 1976: 508）。このようなマンハイムの指摘は，「家族の民主化」 論にとっても示唆に富む. 家族をめぐる「自由」もまた,「規制」の有無ではなく， 「個人的可能性」や「公共の利益」の増進/減退という基準によって把握されるべ きであり，「自由」を確保するための統制が不可欠だといえる.

家族の民主化 $=$ 家族の脱中心化は, 家族構造からの家族機能の分化を通じて, 個 人が直面するリスクをより広範な社会関係のなかで分有していこうという理念であ り，その意味で，「個人の選択・自由」といった主体性の促進が，そのまま社会的 連带の促進へ連結するという構造をもった理念である. エスピンーアンデルセンも 示唆するとおり，「福祉の脱家族化」を図ることは，決して「家族に対する積極的 な支援」を行うことと矛盾しない.

以上みてきたように,「家族の民主化」は今なお実現されていない〈未完のプロ ジェクト〉である。 もち万ん, 「家族の民主化」は, 個人や社会を画一化ないし硬 直化させるための理念であってはならない9). 丸山眞男が述べたように，「民主主 義」とは,「制度の自己目的化」を警戒し「制度の現実の働き方を絶えず監視し批 判する姿勢によって, はじめて生きたものとなり得る」のであり,「不断の民主化 によって辛うじて民主主義でありうる」（丸山 1961：156-7）。家族社会学の〈未完 の〉課題として継承すべき「家族の民主化」もまた，このような「不断のプロセ ス」のことにほかならない.

\section{5 結 論}

以上，本稿では「家族の民主化」論の再考を通じ，「家族の民主化」が今なぜ重 要なのかを明らかにしてきた，本稿は，戦後の民主化論が「家族の例外化」に立脚 してきたことを問題ととらえ (第 2 節)，「家族の民主化」の実現可能性をギデンズ の議論から探った (第 3 節)。そして, ギデンズの議論を「家族の脱中心化」論へ と接続することで, 今なぜ「民主化」が重要な理念たりうるのかを明らかにした 
(第 4 節)。もちろん，本稿で提示した議論の多くは抽象的な次元にとどまるもので あり，「民主化」の理念の有効性は，具体的な文脈における今後の実証研究によっ て検証されるべきものである。しかし，本稿の知見は家族社会学研究に多くの示唆 を与えると考える.

第 1 に, 家族社会学が直面する「アイデンティティの拡散」（渡辺 1996; 田渕 2006; 池岡 2010）という状況への示唆である. 戦後から現在までの家族社会学の 軌跡を「民主化」という軸で再構成した本稿は，核家族を前提とした「標準理論」 が崩れ, 家族社会学の多様化が進み,「家族に対して社会学的に接近することの独 自性」が摇らぎ，「家族社会学がどのような方向へ進むべきかが真剣に考えられる べき」（田㴊 2006：961）時代にあって，1つの方向性を示す試みだと考える。また， 渡辺秀樹（1996）は，「家族社会学のアイデンティティ拡散」に対する危惧から, 〈家族社会学の社会学〉と呼ぶべき知識社会学的検討の必要を主張したが, 限定的 であるとはいえ，本稿をその試みの 1 つと位置づけることもできるだろう.

本稿の第 2 の意義は, 家族社会学の実践的な分析枠組みや理論構築のための視点 を提供したことにある。「近代家族」批判や「個人化」批判という家族社会学の取 り組んできた相対化作業は，ともすると「ニヒリズム」に陥る危険を有している. これらの功績をニヒリズムから脱却させるために，そして，「社会学的な家族研究 が何らかの『問題解決』に寄与する能力を高めるため」（田㴊 2006：957）にも, 「家族の民主化」という理念をふたたび家族社会学の中心的な課題へと引きもどす ことが重要であると考える.

本稿の第 3 の意義は, 「個人化」と「社会的連帯」の相克をどうのりこえるかと いう，家族社会学にかぎらず社会学全体が直面している課題への手がかりを提供す る点にある. 今後の家族社会学が取り組むべき課題もまた，川島が提起していた 「家族」と「民主主義」の対立をどう克服するかという，古くて新しい課題ではな いだろうか. 現在進行中の「個人化」や「多様化」がもたらした諸問題に対応する 際，家族の領域においても「民主主義の危機は民主主義が十分に民主的でないこと に由来する」（Giddens 1998: 71）という認識に立つことが必要である.

1956 年, 「家族制度復活論」が高まる時代に, 磯野夫妻は, 戦前と戦後の家族を めぐる価值体系の転倒とそれが人々に与えた心理的影響を次のように表現した.

太陽が地球のまわりを迴っているとばかり思っていたのに, 実は地球の方が 太陽をまわっているのだと聞かされたと同じほどの，心理的宙返りを人々に要 求した. そして現象としては太陽の方が動いているとしか見えないことが地動 説を人々に信じ難くしたように, 戦後現れた多くの社会問題は, 新しい価值体 系の欠陥を証明するものとして感じられ, それらの問題の対策として古い体系 への復帰を要求する声も出てきた。（磯野・磯野 1956：117）

おそらくこのアナロジーは,「個人化」に伴う家族のリスク化や階層化が顕在化 
している現代の社会状況を考えるうえでも有効だろう。「個人化」の進展が人々の 生活のリスクを高め, 不安定なものにしている現実を前に,「家族の民主化」こそ が追求されるべき理念なのだと説く本稿の主張は,「家族の解体」こそがまさに現 在の不遇の要因にほかならないと感じている人々にとっては, 非現実的な理想論に しか映らないかもしれない，その意味で，多くの人々が「伝統」や「家族」への回 州に誘われることはある程度不可避な現象なのかもしれない. しかし，それでもな

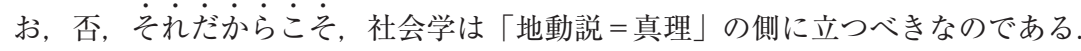

\section{[注]}

1）有地亨（1977）も参照されたい. 民法典論争に象徴されるように, 家族主義と民主主義の対 立にどう対処すべきかという問題は明治期にも活発であった。 また，この問題に関しては結婚 の規範に限定したものだが, 阪井裕一郎（2009）の議論も参照してほしい.

2） 2 つの用語については本稿でより詳しく論じていく. もちろん個人化の要因は民主化のみに 還元しえない. 新自由主義やグローバル化に伴う経済状況の変化が個人化をもたらす側面もあ る.だが本稿では, 要因は何であれ家族の「解消可能性」と「選択可能性」の増大という「実 態」を示す概念として「個人化」を用いる. 同様に「家族の多様化」も「実態」を示す概念と して用いる.

3）森岡清美によれば，それまで「家族研究」あるいは「家族論」と呼ばれた家族の社会学的研 究が,「家族社会学」の名称で呼ばれるようになるのは1953 年頃であった（森岡 1974: 347）.

また, 1950 年〜 60 年代の家族研究の動向については池岡（2009）の整理を参照されたい.

4） 1954 年 11 月, 自由党憲法調查会は, 「家族制度復活」を掲げた「日本国憲法改正要綱」を発 表した，その内容は，明確に「封建的家族制度」を否定しつつも，「血族共同体の保護と尊重」 「親の子に対する扶養および教育の義務」「この親に対する孝養の義務」等を取り入れたものだ つた（湯沢 1977: 45）.

5）さらに，北村や磯野夫妻も「愛」を「理性」と結びつけることで，家族の結合を脅かす愛の 不安定性を乗り越えようと考えた。だが,こうした「愛」の重要性を肯定しつつ危険視し, 「理性」と結合しようというロジックは明治期以降, 保守的な知識人の論稿に一貫してあらわ れるものであった（阪井 2009).

6）U.ベックも依存を必要とする子どもの存在を根拠に, 家族の民主主義は不可能だとみなす (Beck 1997). しかし, 家族内部にかぎらず社会全体の視点から見ても「子ども」は存在する のであり，子どもを理由に“家族にのみ”民主主義は不可能とみれば，それは家族例外論にな る.

7）わずかながら具体例を挙げておく．DVや虐待など暴力に直面した際に離婚という主体的選 択を行うこと, あるいは, 介護や子育てのようなケアと自らのキャリアの両立を試みる場面に おいて,「個人の権利」の行使が, 家族外関係による保護の不可欠性を社会に要請することに つながると同時に，そもそも個人の権利・自由を行使するためには，家族外的な保護・支援の 関係が存在していることが不可欠である。

8）丸山も,「戦後民主主義」批判を展開する論者に対し，「自由が本当に奪われた状態，ホッブ ズのいう自然状態に対する想像力がないから……逆に『無秩序』にたいするあこがれが共同体 的意識の上にのっかって出てくる」と述べ,「自由」を無秩序・無規範状態とみなす自由観を 批判した（丸山 [1958] 1998: 133）. 
9）当然ながら，私領域の民主化は公領域の民主化と連動するものであり，われわれは公領域の 民主化の推進のなかで「家族の民主化」を検討する必要がある.

\section{[文献]}

有地亨, 1977, 『近代日本の家族観・明治篇』弘文堂.

Bauman, Z., 1993, “The Review of The Transformation of Intimacy," Sociological Review, 41: 363-8.

Beck, U., 1997, “Democratization of the Family," Childhood, 4(2) : 151-68.

Bologh, R. W., 1994, "Review of The Transformation of Intimacy," Contemporary Sociology, 23: $845-6$.

Budgeon, S. and S. Roseneil, 2004a, "Editors' Introduction: Beyond the Conventional Family," Current Sociology, 52(2) : 127-34.

—, 2004b, “Culture of Intimacy and Care Beyond 'the Family' : Personal Life and Social Change in the Early 21st Century," Current Sociology, 52(2) : 135-59.

Burgess, E. W. and H. J. Locke, 1945, The Family: From Institution to Companionship, New York: American Book.

Durkheim, É., 1893, De la division du travail socia, Paris: Felix Alcan.（=1971，田原音和訳『社会分 業論』青木書店. )

Esping-Andersen, G., 2008, Trois leçons sur l'État-providence, Document Transcript, Paris: Seuil. （=2008，林昌宏訳『アンデルセン，福祉を語る——女性・子ども・高齢者』NTT 出版. )

Folsom, J. K., 1949, The Family and Democratic Society, London: Routledge.

Giddens, A., 1992, The Transformation of Intimacy, Cambridge: Polity Press. , 1994, Beyond Left and Right: The Future of Radical Politics, Cambridge: Polity Press.

- 1998, The Third Way: The Renewal of Social Democracy, Cambridge: Polity Press.

- and C. Pierson, 1998, Conversations with Anthony Giddens: Making Sense of Modernity, Stanford: Stanford University Press.

池岡義孝，2009，「第 I 期解説」渡辺秀樹 - 池岡義孝監修『戦後家族社会学文献選集 解説 · 解題』

日本図書センター, 15-30.

—, 2010,「戦後家族社会学の展開とその現代的位相」『家族社会学研究』22(2)：141-53.

磯野誠一・磯野富士子, 1956,「家族の新しいモラルと古いモラル」磯村英一・川島武宜・小山隆

編『現代家族講座 2 結婚への道』河出書房, 93-134.

—，1958，『家族制度——淳風美俗を中心として』岩波書店.

岩間暁子, 2010,「日本に打ける『社会階層と家族』の研究を振り返る——階層研究と家族社会学 の架橋のために」『家族社会学研究』22(2): 177-89.

Jamieson, L., 1999, “Intimacy Transformed? A Critical Look at the 'Pure Relationship' ,’ Sociology, 33(3) : 477-94.

川島武宜, [1946] 2000,「日本社会の家族的構成」『日本社会の家族的構成』岩波書店, 1-30.

—, 〔1947〕2000,「イデオロギーとしての『孝』」『日本社会の家族的構成』岩波書店,

$87-148$.

北村達, 1955, 『近代家族』大明堂.

小玉亮子, 2010,「〈教育と家族〉研究の展開——近代的子ども観・近代家族・近代教育の再考を軸

として」『家族社会学研究』22(2) : 154-64. 
久保田裕之, $2009 \mathrm{a}$, 『他人と暮らす若者たち』集英社.

—, 2009b,「若者の自立/自律と共同性の創造——シェアハウジング」牟田和恵編『家族を 超える社会学——新たな生の基盤を求めて』新曜社, 104-36.

—, 2011, 「家族社会学に打ける家族機能論の再定位—〈親密圈〉・〈ケア圈〉・〈生活圈〉

の構想」『大阪大学大学院人間科学研究科紀要』37: 79-96.

Mannheim, K., 1951, Freedom, Power \& Democratic Planning, London: Routledge.（=1976, 田野崎

昭夫訳「自由・権力・民主的計画」『マンハイム全集 6』潮出版社. )

丸山眞男，［1958］1998，「民主主義の原理を貫くために」『丸山眞男座談 5』岩波書店，115-43.

—, 1961, 『日本の思想』岩波書店.

森岡清美, 1974, 「日本の家族研究における家族問題」家族問題研究会編『現代日本の家族——動

態・問題・調整』培風館, 341-57.

牟田和恵, 1996, 『戦略としての家族——近代日本の国民国家形成と女性』新曜社.

， 1999，「川島武宜著『日本社会の家族的構成』」筒井清忠編『日本の歴史社会学』岩波書

店, 123-33.

Pahl, L. and L.Spencer, 2004, "Personal Communities: Not Simply Families of 'Fate' or

'Choice', Current Sociology, 52(2) : 199-221.

阪井裕一郎, 2009,「明治期『媒酌結婚』の制度化過程」『ソシオロジ』54(2)：89-105.

Santore, D., 2008, "Romantic Relationship, Individualism and the Possibility of Togetherness:

Seeing Durkheim in Theories of Contemporary Intimacy," Sociology, 42(6) : 1200-17.

千田有紀, [1999］2002,「家のメ夕社会学——家族社会学における『日本近代』の構築」佐々木潤

之介編『家族史の方法』吉川弘文館, 276-317.

—, 1999,「家族社会学の問題構制——家』概念を中心として」『社会学評論』50 (1) :

91-104.

—, 2010,「フェミニズム論と家族研究」『家族社会学研究』22(2)：190-200.

田渕六郎, 2006, 「分野別研究動向 (家族)」『社会学評論』56(4)：950-63.

上野千鶴子, 1994, 『近代家族の成立と終焉』岩波書店.

一，2009，「家族の臨界——アアの分配公正をめぐって」厸田和恵編『家族を超える社会学』

新曜社, $2-26$.

我妻榮, 1948, 『家の制度——その倫理と法理』酣燈社.

渡辺秀樹, 1996,「転換期の家族社会学——シポジウムの司会を担って」『家族社会学研究』8:

3-5.

山田昌弘, 1994, 『近代家族のゆくえ——家族と愛情のパラドックス』新曜社.

—, 1999,「愛情装置としての家族」目黒依子・渡辺秀樹編『講座社会学 2 家族』東京大学 出版会, 119-51.

—, 2004, 「家族の個人化」『社会学評論』54(4): 341-54.

山手茂, 1972, 『現代日本の家族問題』亜紀書房.

—, 1975, 「家族問題と家族社会学」北川隆吉監修『戦後日本の社会と社会学 2 社会・生活

構造と地域社会』時潮社, 1-47.

湯沢雍彦, 1977, 「家族問題の戦後史」『ジュリスト増刊総合特集 6 現代の家族』41-8.

(原稿受付 2011.6.11 掲載決定 2011.12.8) 


\title{
The Uncompleted Project of "Democratizing the Family": Focusing on Postwar Family Studies
}

\author{
SAKAI, Yuichiro \\ Keio University \\ yuichiro.sakai@hotmail.co.jp
}

In early postwar Japan, the democratization of social relationships was the most essential and inevitable ideal. Scholars at that time in the field of family studies have tried to consider how the "democratization of the family" was realized. These studies certainly had limitations, in that they regarded the familial relationship as exceptional when compared to other social relationships. However, their ideals don't lose significance in themselves. Although the ideal of "democratization of the family" has been criticized and ignored by sociologists, we must reconsider these criticisms and take this ideal back.

Recently, Anthony Giddens has idealized "intimacy as democracy" or the "democratic family," with the emergence of what he calls a "pure relationship." His ideal, which might seem to be an anachronism, has been criticized by many sociologists in terms of his ignorance of economic factors, his optimism and so on. However, I regard these criticisms as being derived from misunderstandings of Giddens's idea of the transformation of intimacy. This paper will reconsider the intention of Giddens and clarify why "democratization of the family" matters in late modernity. The result will suggest that the democratization of the family depends on the "decentralization of the family," though that sounds paradoxical. To decentralize the family is the ideal which argues a wide range of relationships must share individual risks through separating family functions from family structures. In this sense, this ideal combines 'individual autonomy' and 'social solidarity'. The democratization of family promotes the decentralization of family, or vice versa. This is why we must defend and value the democratization of the family. Now we need to reevaluate the democratization of the family, and therefore its decentralization, as an uncompleted project.

Key words: democratization of the family, transformation of intimacy, decentralization of the family

(Received Jun. 11, 2011 / Accepted Dec. 8, 2011) 